\title{
Plantes sahéliennes adaptées dans la récupération des terres dégradées et leurs usages pour la santé : cas de la province du Soum au Nord du Burkina Faso
}

Alphonsine RAMDE-TIENDREBEOGO ${ }^{1,6 *}$, Roger ZERBO ${ }^{2,6}$, Bassiriki OUATTARA $^{3}$ Adama DOULKOM ${ }^{4}$, Innocent Pierre GUISSOU ${ }^{5}$

${ }^{1}$ Département de Médecine et Pharmacopée Traditionnelles-Pharmacie/Institut de Recherche en Sciences de la Santé

(MEPHATRA-PH/IRSS), Centre National de la Recherche Scientifique et Technologique, 03 BP 7192 Onagadongon

03, Burkina Faso

${ }^{2}$ Département Socio-économie et Anthropologie du Développement/ Institut des Sciences des Sociétés (INSS) / Centre

National de la Recherche Scientifique et Technologique

03 BP 7047 Onagadongon 03, Burkina Faso

${ }^{3}$ Laboratoire de Biologie et Ecologie végétale/ Unité de Formation et de Recherche en Sciences de la Vie et de la Terre/

Université Onaga I Pr Joseph Ki-ZERBO, 03 BP 7021 Onagadongou 03, Burkina Faso.

${ }^{4}$ Initiative de la Grande Muraille Verte pour le Sabara et le Sabel (IGMVSS)/Ministère de l'Environnement, de

l'Economie Verte et du Changement Climatique/ Burkina Faso. 03 BP 7044 Onagadougou 03, Burkina Faso

${ }^{5}$ Université Saint Thomas d'Aquin (USTA), Faculté des Sciences de la Santé (FSDS) / 06 BP 10212 Onagadougou 06

Burkina Faso

${ }^{6}$ Unité Mixte Internationale -Environnement, Santé, Sociétés (UMI 3189, ESS) CNRS/UCAD/UGB/

USTTB/CNRST

*Auteur correspondant; E-mail: ramdalphonsine@gmail.com; Tel (+226) 74494355

Mots clés : Sahel, reforestation, Soum, plantes médicinales, environnement.

Keywords: Sahel, reforestation, Soum, medicinal plants, environment.

Publication date 31/07/2019, http://www.m.elewa.org/JAPS;

\section{RESUME}

Objectif: Le Burkina Faso, à l'instar des pays du Sahel subit une forte dégradation des terres suite à des sécheresses successives et aux activités anthropiques. La plantation des arbres demeure l'activité capitale pour restaurer l'écosystème sahélien. Cependant, le principal souci consiste à mettre en place une gestion durable des sites restaurés. L'objectif de cette étude est de faire connaitre les usages en médecine traditionnelle des espèces végétales les mieux adaptées dans la récupération des terres dégradées au nord du Burkina Faso.

Méthodologie et résultats : Une enquête ethnobotanique a été menée dans 08 villages de la province du Soum au nord du Burkina Faso pour connaitre les plantes de cette région et les pratiques médicales traditionnelles des populations. Les résultats ont montré que 53 espèces réparties en 28 familles et 44 genres ont été répertoriées. Les FabaceaeMimosoideae, les Combretaceae, les Fabaceae-Caesalpinioideae et les Anacardiaceae étaient les familles les mieux représentées. Les maladies les plus rencontrées par les populations qui y vivent et traitées avec les plantes étaient les infections/infestations $(20 \%)$, les troubles du système digestif $(18 \%)$, les troubles gynéco-obstétrique et urologique $(14 \%)$, les troubles cutané-dermatologiques $(14 \%)$.Les feuilles étaient les parties les plus recommandées (43\%) dans les recettes. La décoction $(45 \%)$ comme mode de préparation des recettes et la voie orale comme mode d'administration $(50 \%)$ étaient les plus indiquées. Vu le caractère particulier de la zone d'étude qui est fortement pastorale, $19 \%$ des plantes répertoriées étaient aussi utilisées pour les soins du bétail.

Conclusion et application des résultats : Ces résultats constituent une base de données scientifique sur l'utilisation des espèces sahéliennes pour la santé en médecine 
traditionnelle. La valorisation des vertus thérapeutiques des plantes sahéliennes contribuerait à une gestion rationnelle de la biodiversité végétale, et serait une alternative pour une pérennisation des terres récupérées, voire une reforestation à grande échelle.

Sahelian plants adapted in the recovery of degraded lands and their uses for health: case of the Soum province in northern Burkina Faso

\section{ABSTRACT}

Objective: Burkina Faso, like the Sahel countries suffers a major land degradation following successive droughts and human activities. The planting of trees remains the key activity to restore the Sahelian ecosystem. However, the main concern is to put in place a sustainable management of restored sites. The objective of this study is to make known the uses in traditional medicine of the plant species at best to the recovery of degraded lands in the north of Burkina Faso.

Methodology and results: An ethnobotanical survey was conducted in 08 villages in the Soum province of northern Burkina Faso to find out about the plants of this region and the traditional medical practices of populations. The results showed that 53 species divided into 28 families and 44 genera were listed. Fabaceae-Mimosoideae, Combretaceae, Fabaceae-Caesalpinioideae and Anacardiaceae were the most represented families. The most common diseases encountered by the populations living there and treated with plants were infections / infestations $(20 \%)$, disorders of the digestive system (18\%), gynecological and obstetric disorders (14\%), skin-dermatological $(14 \%)$. Leaves were the most recommended parts $(43 \%)$ in recipes. Decoction $(45 \%)$ as a method of recipe preparation and the oral route as the method of administration $(50 \%)$ were the most appropriate. Due to the special character of the study area which is highly pastoral, $19 \%$ of the listed plants were also used for livestock care.

Conclusion and application of results: These results constitute a scientific database on the use of Sahelian species for health in traditional medicine. The valorization of therapeutic virtues of Sahelian plants would contribute to a rational management of plant biodiversity and would be an alternative for a perpetuation of reclaimed land, or even a large-scale reforestation. 